\title{
Banking
}

\section{The latest edition of the code of practice}

\section{by Andrew Campbell}

The third edition of the code of banking practice, entitled The Banking Code, came into effect on 1 July 1997 just over five years from the introduction of the code's first edition. The code was originally introduced as a result of the report of the committee which had been appointed to undertake a review of the law relating to banking services. The response of the Conservative government of the time was that 'non-statutory selfregulation' would be more appropriate than legislation and, as a result, the banking code was introduced in March 1992 having been prepared by the British Bankers' Association, the Building Societies' Association and the Association for Payment Clearing Services.

At the time of its introduction the code was both welcomed and criticised by consumer groups. It was welcomed as a significant development in the protection of personal customers but was criticised for failing to provide that protection at an adequate level and for having failed to deal with a number of important issues. When the second version was published in 1994 it was immediately criticised by the director general of the Office of Fair Trading who felt that an opportunity to increase consumer protection had been wasted and other consumer bodies, including the Consumers' Association, were also critical.

\section{CODE'S NATURE}

The banking code is a voluntary code which applies only to personal customers in the UK and which sets out minimum standards of good banking practice. The banking ombudsman scheme, unlike the code, applies also to small businesses and the failure of the latest version of the code to include sole traders, partnership accounts and small companies is regrettable.

\section{PUBLIC AWARENESS}

At present the code is not as widely known as it should be to bank staff, let alone the public

it is to be hoped ... that the code will be on display at all branches of banks which subscribe to it and be freely available to customers.
The banking ombudsman has noted that ensuring that the code's existence is widely known and that copies are easily available is almost as important as having a code which is satisfactory. At present the code is not as widely known as it should be to bank staff, let alone the public. There has been some doubt about the level of commitment shown by banks to the code and it is interesting to note that the new version has been produced in a smaller and presumably cheaper manner than the previous ones. It is to be hoped that this reflects the desire of the ombudsman and others that the code will be on display at all branches of banks which subscribe to it and be freely available to customers.

\section{THE LATEST VERSION}

The first significant change is that the code sets out $11 \mathrm{key}$ commitments to customers. These are that banks and building societies will:

\section{'(I) act fairly and reasonably;}

(2) ensure that all services and products comply with the code, even if they have their own terms and conditions;

(3) give you information on services and products in plain language, and offer help if there is any aspect which you do not understand;

(4) help you to choose a service or product to fit your needs;

(5) help you to understand the financial implications of: a mortgage; other borrowing; savings and investment products; card products;

(6) help you to understand how your accounts work;

(7) have safe, secure and reliable banking and payment systems;

(8) ensure that the procedures staff follow reflect these commitments;

(9) correct errors and handle complaints speedily;

(10) consider cases of financial difficulty and mortgage arrears sympathetically and positively;

(II) ensure that all services and products comply with relevant laws and regulations.'

\section{INNOVATIONS}

One of the most significant changes contained in the new code, and one which was strongly advocated by the banking ombudsman, is the commitment not to take unlimited guarantees from personal customers. In addition, the code makes it a requirement that a bank must advise guarantors of what the limit of their liability under the guarantee will be. Banks have come under increasing criticism in relation to the use of unlimited guarantees (see, for example, Crédit Lyonnais Bank Nederland NV v Burch (1997) 1 AER 144) and this new commitment is a welcome development. However there still remains the problem

\section{GUARANTEES}

One of the most significant changes contained in the new code, and one which was strongly advocated by the banking ombudsman, is the commitment not to take unlimited guarantees from personal customers. In addition, the code makes it a requirement that a bank must advise guarantors of what the limit of their liability under the guarantee will be.

of those who have provided unlimited guarantees which are still in existence. It is as yet unclear whether the banks involved will ensure that these are all replaced with limited guarantees.

Prior to July 1997 a bank which subscribed to the code was expected but not required to be a member of the banking ombudsman scheme; but under the terms of the new version of the code all subscribers must either belong to the banking ombudsman scheme or, where appropriate, the building societies' ombudsman scheme, the Finance and Leasing Association arbitration scheme or the Consumer Credit Trade Association arbitration scheme.

A new section entitled Helping You To Choose a Mortgage has been introduced and this outlines the three levels of service which banks may provide. These are:

(1) advice and a recommendation 
(2) information on the different types of mortgage products which are offered and

(3) information on a single mortgage product only.

Confirmation in writing of the level of service given is to be provided to the customer. Banks will be able to decide for themselves whether to offer option (1) but for those who do the service is to be available by 31 March 1998 .

\section{SIGNIFICANT STEP}

The purpose of this note is to draw attention to some of the changes introduced by the latest version of the code and no attempt has been made to provide a detailed account of its provisions. The changes have been described by the Office of Fair Trading (OFT) as a significant step forward as they contain some of the recommendations made by the OFT and by the ombudsman.

The combination of the existence of the code and the ombudsman scheme provides personal customers with a level of protection, coupled with the availability of a cost-effective dispute resolution method, and this should be of great benefit to customers. The cost of litigation and the lack of availability of legal aid for most customers ensures that action through the courts is not a viable alternative for many customers who are in dispute with their banks. However, it is unfortunate that the latest version of the code only applies to personal customers, and is therefore narrower in scope than the ombudsman scheme.

Perhaps the major issue is whether the banks who subscribe to the banking code will show a level of commitment which

\section{CUSTOMER SERVICE}

The combination of the existence of the code and the ombudsman scheme provides personal customers with a level of protection coupled with the availability of a cost-effective dispute resolution method and this should be of great benefit to customers.

reflects the code's importance. Will staff receive adequate training and will copies of the code be available at bank branches? Bank staff will only treat the code seriously if the senior management indicate a clear commitment to it. Prior to the introduction of the third version there was some doubt about this.

Andrew Campbell

University of Wales, Aberystwyth

\section{EU Focus}

\section{Essential Developments in EU Law and Policy}

$E U$ Focus is a fortnightly magazine devoted to keeping the reader fully informed on all the latest European Union legal news and issues.

\section{Topical, reliable and impartial information}

Each issue features a lead article on a current topic followed by items on areas of key legal interest such as:

- company law

- environment

- taxation

- energy

- trade matters

- food

- litigation and remedies
- competition

- the single market

- transport

- customs

- social policy

- agriculture

- justice and home affairs
- employment

- state aid

- EMU

- health and safety

- external relations

- IT/telecommunications

- principles of EC law

Two regular features of the magazine of vital use to the practitioner are OJ Update, which lists items of importance from recent issues of the Official Journal of the European Communities, and Court Calendar, which provides information on judgments and opinions scheduled to be handed down by the Court of Justice and the Court of First Instance.

\section{Free copy - special offer to Amicus Curiae readers}

As a reader of Amicus Curiae, CCH Editions is pleased to offer you the chance to receive a free copy of EU Focus. Simply call CCH Editions' Customer Services team on (01869) 872336 or fax your request on (01869) 874700 . Please be sure to mention that you heard of this promotion through Amicus Curiae. If you should then decide to take out a full year's subscription at a cost of $£ 171$, you will receive 22 issues of EU Focus. 